\title{
DAMPAK PENERAPAN KURIKULUM KEMENTERIAN AGAMA DAN KURIKULUM PESANTREN TERHADAP PENINGKATAN HASIL BELAJAR PAI DI MAN YOGYAKARTA I
}

\author{
Oleh: \\ Ainna Khoiron Nawali \\ Mahasiswa Magister UIN Sunan Kalijaga Yogyakarta \\ ainnawali@gmail.com
}

\begin{abstract}
Abstrak
Latar belakang penelitian ini adalah berawal dari semakin banyaknya Madrasah maupun Sekolah umum yang menerapkan kurikulum pesantren sebagai kurikulum penunjang kurikulum di sekolah / madrasah khususnya pada mata pelajaran Pendidikan Agama Islam (PAI). Hal tersebut yang membuat beberapa lembaga pendidikan mendirikan Pondok, Asrama, atau Boarding School, guna mendorong program sekolah tersebut. Begitupun juga yang terjadi di MAN Yogyakarta I, disanapun juga mendirikan pondok pesantren "Al Hakim" untuk menambah cakrawala santri terhadap referensi keilmuan islam. Yang menjadi permasalahan, bagaiman dampak yang ditimbulkan dengan penerapan kurikulum kemenag dan kurikulum pesantren terhadap peningkatan hasil belajar PAI. Tujuan dari dilakukannya penelitian ini adalah untuk mengetahui bagaimana dampak penerapan dua kurikulum (Kurikulum Kemenag dan Kurikulum Pesantren) terhadap peningkatan hasil belajar PAI di MAN Yogyakarta I dan juga untuk mengetahui kelebihan dan kekurangan dalam dua penerapan kurikulum tersebut. Penelitian ini menggunakan jenis penelitian kualitatif. Hasil penelitian ini menunjukkan bahwa : (1) Dalam penerapannya, Kurikulum pesantren hanya sebagai materi pendukung, artinya kurikulum kemenag masih menjadi prioritas utama dibanding kurikulum Pesantren. (2) Dampak dan pencapaiannya dalam penerapan dua kurikulum tersebut mempunyai dampak positif terhadap hasil belajar PAI pada siswa, seperti nilai siswa ponpes lebih bagus dari pada nilai siswa non ponpes dari segi ranah kognitif, afektif dan psikomotorik (3) Kelebihannya dua kurikulum diterapkan secara baik, akan membuat siswa semakin banyak menguasai materi pelajaran agama, sehingga akan mendongkrak nilai ujian. Namun kekurangannya terjadi ketidak sesuaian antara materi kurikulum kemenag dan kurikulum pesantren, karena materi yang tidak disampaikan secara berurutan dan juga alokasi waktu yang sangat sedikit.
\end{abstract}

Keyword : Kurikulum, Hasil Belajar, Pendidikan Agama Islam 


\begin{abstract}
The background of this research is originated from the increasing number of Madrasah and general school curriculum of schools as a curriculum support curriculum in schools / madrasah, especially on the subjects of Islamic Religious Education (PAI). That makes some institutions maintain lodge, hostel, or Boarding School, in order to encourage the school program. Likewise also the case in MAN Yogyakarta I, even there also established boarding schools "Al Hakim" to increase the horizon of students towards scientific references to Islam. The problem, how the impact caused by the implementation of curriculum kemenag and boarding school curriculum to increase learning outcomes PAI. The purpose of this study was to determine how the impact of the application of two curriculum (Curriculum kemenag and Curriculum boarding school.) to increase learning outcomes PAI in MAN Yogyakarta I and also to determine the advantages and disadvantages of the two application of the curriculum. This study uses qualitative research. The results showed that: (1) In practice, the only boarding school curriculum as support materials, curriculum kemenag remains a priority than boarding school curriculum. (2) Impact and achievements in the implementation of the two curricula have a positive impact on learning outcomes of PAI in students, such as boarding school students better value than on the value of nonboarding school students in terms of cognitive, affective and psychomotor (3) Excesstwo curricula are applied properly, will create more and more students master the subject matter of religion, so that it will boost test scores. However, drawbacks occur discrepancy between the curriculum kemenag and the curriculum boarding school, because the materials are not delivered sequentially and also allocated very little time.
\end{abstract}

Keywords : Curriculuml, Learning Outcomes, Islamic Religious Education

\title{
Pendahuluan
}

\section{A. Latar Belakang}

Dewasa ini lembaga pendidikan Islam, khusunya madrasah bahkan pesantren mengalami banyak tantangan untuk menghadapi arus globalisasi dan modernisasi. Sehingga madrasah dan pesantren harus menyesuaikan dengan tuntutan pengembangan yang secara otomatis akan berdampak pada penetapan kurikulum yang mengikuti istsitusi tersebut. 
Keberadaan pondok pesantren sebagai lembaga pendidikan masyarakat yang sejak awal telah mampu megakomodasi berbagai macam perubahan, baik dalam segi struktural maupun sistematik pengajaran, setelah di amati, transformasi yang ada dalam pesantren, telah membawa lembaga ini mempunyai peran ganda, yaitu sebagai lembaga pendidikan dan pengembangan masyarakat.(Abu Hamid, 2008: 3).

Tidak dapat dipungkiri, bahwa program pembelajaran pada pondok pesantren khususnya dalam bidang pembinaan keimanan dan ketaqwaan akan membentuk masyarakat dan bangsa Indonesia yang berkepribadian dan berbudi pekerti luhur. Namun demikian, perlu diingat, bahwa pembentukan watak dan karakter harus juga dikembangkan secara terintegrasi dengan semua mata pelajaran di pondok pesantren, karena jika tidak terintegrasi dengan baaik, tentu akan mempengaruhi pembentukan watak dan karakter seseorang. Pola yang diajarkan di pesantren adalah sebagai berikut :

a. Pengajaran kitab klasik

b. Madrasah, di pesantren ini diadakan pendidikan dengan model madrasah, selain mengajarkan mata pelajaran juga mengajarkan pelajaran umum. Kurikulum madrasah pondok pesantren dapat dibagi menjadi dua bagian, Pertama, kurikulum yang dibuat oleh pondok sendiri. dan Kedua, kurikulum pemerintah dengan memodifikasi materi pelajaran agama.

c. Ketrampilan juga diajarkan dengan berbagai kegiatan ketrampilan.

d. Sekolah umum, di pesantren ini juga dilengkapi sekolah-sekolah umum. Materi pelajaran umum pada sekolah umum yang ada di pesantren seluruhnya berpedoman pada kurikulum departemen pendidikan nasional. Sedangkan materi pelajaran agama disusun oleh pondok sendiri. Di luar kurikulum pendidikan agama yang diajarkan di sekolah, pada waktu-waktu yang sudah terjadwal, santri menerima pendidikan agama melalui membaca kitab-kitab klasik.

e. Perguruan tinggi. Pada beberapa pesantren yang tergolong pesantren besar, telah membuka universitas atau perguruan tinggi.(Anin Nurhayati, 2010:66-67)

Kemudian, jika dilihat dari tipe/format, pendidikan pesantren dapat diklaisifikasikan menjadi empat tipe. Yakni :

1) Pesantren yang menyelenggarakan pendidikan formal dengan menerapkan kurikulum nasional, baik yang memiliki sekolah keagamaan (MI, MTs, MA dan PT. Agama Islam) maupun yang juga memiliki sekolah umum (SD, SMP, SMA dan PT. Umum), seperti Pesantren Tebu Ireng Jombang, dan Pesantren Syafi'iyah Jakarta. 
2) Pesantren yang menyelenggarakan pendidikan keagamaan dalam bentuk madrasah dan mengajarkan ilmu-ilmu umum meski tidak menerapkan kurikulum nasional, seperti Pesantren Gontor Ponorogo dan Dar al-Rahman Jakarta.

3) Pesantren yang hanya mengajarkan ilmu-ilmu agama dalam bentuk madrasah diniyah (MD), seperti pesantren lirboyo Kediri dan Pesantren Tegalrejo Magelang. dan

4) Pesantren yang hanya sekedar menjadi tempat pengajian. (M. Shulton Masyhud, 2005:5)

Dari keempat tipe pesantren tersebut, dua diantaranya yang tipe pertama dan kedua merupakan representasi pesantren modern. Sementara yang ketiga dan keempat merupakan representasi pesantren tradisional.

Walupun demikian, secara umum masing-masing pesantren mempunyai relatif kesamaan dalam penyajian materi kurikulumnya. Hal ini bisa dilihat dari komponen materi yang disajikan, seperi : Bahasa, al-Qur'an, al-Hadits, Tauhid, Fiqh, dan komponen tasawuf. Bahkan dari beberapa komponen tersebut, beberapa pesantren ada yang sudah melakukan rekonstruksi kurikulumnya, sehinga di tambah dengan komponen ketrampilan, wawasan dan metodologi.(Anin Nurhayati, 2010:67).

Untuk itulah madrasah mulai menerapkan kurikulum Kementerian Agama (Kemenag) dengan kurikulum pesantren. Banyak sekolah yang menerapkan dua kurikulum tersebut dalam proses belajar mengajarnya, baik di sekolah maupun di asrama (pondok). Seperti yang ada di pondok pesantren Al Hakim di MAN Yogyakarta 1.

Hasil wawancara dengan Bapak Dzulhaq Nurhadi, M.Pd.I, Selaku Pengurus PP. Al Hakim Bidang Kesantrian pada 29 Januari 2015. Kurikulum pesantren yang diterapkan di MAN Yogyakarta I ini merupakan seperangkat rencana dan pengaturan muatan yang digunakan dalam penyelenggaraan proses belajar mengajar (PMB) yang mencakup bahan kajian dan mata pelajaran yang meliputi Tafsir Al-Qur'an, Bahasa Arab, Hadits, Fiqh, Nahwu \& Shorof, dan Mahfudzot. Disamping itu terdapat kegiatan ekstra, yaitu : Khitabah minbariyah, Keorganisasian, dan Pelatihan Keterampilan. 
MAN Yogyakarta I mencoba mengajarkan kepada siswa-siswanya selain mendalami ilmu-ilmu umum, juga mendalami ilmu-ilmu agama, sehingga diharapkan siswa tersebut bisa saling melengkapi antara kurikulum pesantren dengan kurikulum kemenag.

Namun yang jadi tanda tanya besar, Apakah semua siswa bisa mempelajari dengan baik ? atau justru dengan penerapan Dua kurikulum tersebut membuat berat siswa dalam belajar, sehingga hasil yang dinginkan sekolah tidak tercapai?.

Penelitian ini menggunakan jenis penelitian kualitatif. Pengumpulan data dengan mengadakan observasi atau pengamatan, wawancara dan dokumentasi. Penelitian ini menggunakan pendekatan sosiologis. Pemeriksaan keabsahan data dengan menggunakan teknik triangulasi. Selanjutnya analisis data dilakukan dengan menyeleksi dan menyusun data yang sudah diperoleh, kemudian diolah dan dianalisis agar dapat ditarik kesimpulan.

\section{B. Pembahasan}

\section{Materi Kurikulum Pesantren}

Dalam penerapan kurikulumnya, di pagi hari ketika sekolah, siswa di ajarkan mata pelajaran Fiqh, maka di Pesantren Santri di ajarkan Mata pelajaran Ushul Fiqh, Siswa di ajarkan mata pelajaran Qur'an Hadits maka di Pesantren di ajarkan mata pelajaran Hadits seperti Arbain Nawawi, Taudhihul Ahkam syarah dari Bulughul Maram, Siswa di ajarkan mata pelajaran Aqidah Akhlak maka di pesantren di ajarkan Jawahir Kalamiyah. Adapun rinciannya sebagai berikut :

Tabel 1. Perbandingan Mata Pelajaran

\begin{tabular}{|l|l|l|}
\hline \multirow{2}{*}{ NO } & Mata Pelajaran & Pesantren \\
\cline { 2 - 3 } & Madrasah & Ushul Fiqih \\
\hline 1 & Fiqih & $\begin{array}{l}\text { Hadits, Tahsin, Tahfidz, Tafsir } \\
\text { Al Qur'an }\end{array}$ \\
\hline 2 & Al Qur'an Hadits & Jawahir Kalamiyah \\
\hline 3 & Aqidah Akhlak & $\begin{array}{l}\text { Durusullughoh, } \\
\text { Shorof. }\end{array}$ \\
\hline 4 & Bahasa Arab & \\
\hline
\end{tabular}


Dari pihak pesantren menemui kesulitan dalam pemilihan materi, karena harus menyesuaikan jadwal di madrasah, dan alokasi waktu hanya sekitar satu jam. oleh karena itu harus memilih materi yang mudah di cerna oleh santri namun materi tersebut mendasar, seperi mempelajari 1 atau 2 Hadits dalam satu jam.

Kelebihan kurikulum pesantren itu lebih komprehenshif, walaupun yang didapatkan siswa sedikit tapi menyeluruh. Contoh saja dalam mata pelajaran Bahasa arab di madrasah. Siswa pada pertemuan pertama sudah di ajarkan materi Naat Man'ut padahal sebelumnya harus memepelajari urutan-urutan yang harus dipahami, seperi Isim, Fi'il, Hurf. Maka siswa yang baru pertama kali mempelajari Bahasa arab pasti bingung, yang kebanyakan dari sekolah umum. Seperti yang sudah di ketahui, disekolah umum mata pelajaran PAI hanya 2 sampai 3 jam, itupun di campur dengan mata pelajaran Fiqih, Quran Hadits, SKI, Bahasa Arab. Dan lain-lain.

Kelebihan kurikulum pesantren yang lain adalah kesempatan siswa dalam memahami materi pelajaran, dan juga lingkungan yang mendukung, seperti belajar bersama dengan teman-temannya, akan membuat pengetahuan siswa yang mondok lebih banyak dari pada siswa non pondok.

\section{Materi Kurikulum Kementerian Agama}

Adapun materi mata pelajaran PAI di MAN Yogyakarta I yang diajarkan kepada siswa adalah Fiqih, Sejarah Kebudayaan Islam (SKI), al-Qur'an Hadits, dan Aqidah Akhlak. Materi PAI di MAN Yogyakarta I dengan Materi pelajaran agama di Pondok pesantren al Hakim terdapat keterpaduan antara ke empat materi tersebut, keterpaduan materi tersebut bisa dilihat melalui :

a. Aspek Sikap

Hasil wawancara dengan Bapak Dzulhaq Nurhadi, M.Pd.I, pada tanggal 28 Maret 2015 menyampaikan cakupan materi selain menyangkut dengan aspek pengetahuan juga mengajarkan aspek sikap misalnya dengan materi saling meghargai, dengan latar belakang golongan bahkan budaya yang berbeda. tidak membuat para santri memilih teman ketika bergaul, tapi santri justru bisa merangkul semua teman santrinya tanpa memebeda-bedakan. Disinilah peran pondok pesantren dalam mengajarkan saling menghargai kepada semua orang. Karena dengan menerapkan sikap saling menghargai sejak dini, membuat santri 
sudah bisa belajar bagaimana memaknai persaudaraan itu dan ketika dewasa nanti bisa mengaplikasikan dalam kehidupan sehari-hari. Sehingga siswa dan santri mampu bersikap baik dalam kehidupan disekolah maupun di masyakarakat.

b. Ekstrakurikuler

Kegiatan ekstrakurikuler PAI dapat mendukung kegiatan intrakurikuler, misalnya kegiatan sholat berjamaah di lingkungan sekolah, infaq, peringatan harihari besar islam, ada juga kegiatan ekstrakurikuler pesantren yang mendukung kemampuan bakat santri, seperti khithabah minbariyah, keorganisasian, dan pelatihan keterampilan.

c. Keterpaduan

Pola pembinaan mata pelajaran PAI di kembangkan dengan menekankan keterpaduan antara kurikulum pesantren dengan kurikulum kemenag di madrasah, untuk itu antara pihak pondok pesantren al-Hakim dengan pihak MAN Yogyakarta I harus sama tujuannya dalam mencapai visi dan misi madrasah maupun pondok pesantren.

\section{Dampak Kurikulum Kementerian Agama dan Kurikulum Pesantren Terhadap Hasil Belajar Siswa Pada Pembelajaran PAI}

Dampak kurikulum Kementerian Agama dan kurikulum pesantren terhadap hasil belajar siswa bisa diperoleh melalui proses penilaian dan pengamatan pembelajaran PAI pada siswa. Pada penelitian ini penulis mengambil sampel di kelas X MIA 3 dan PP. Al Hakim MAN Yogyakarta I, alasan mengapa memilih kelas tersebut karena dikelas tersebut ada banyak siswa yang tinggal di PP. Al Hakim dibanding dengan kelas-kelas lainnya yang nantinya akan diperkuat hasil penelitian dari ponpesnya. Pengamatan dan penilaian mempunyai peran yang sangat penting dalam pembelajaran PAI, sebab melalui penilaian tersebut dapat di ketahui tentang keberhasilan keaktifan siswa guna mendukung program pembelajaran. karena dengan penilaian dan pengamatan tersebut, bisa diketahui keaktifan siswa di kelas, antara siswa yang tinggal di ponpes dengan siswa yang tidak tinggal di ponpes.

Tes hasil belajar dapat di bagi menjadi tiga jenis, yaitu : 1) tes lisan (oral test), 2) tes tertulis (written test), 3) tes tindakan atau perbuatan (performance 
test). Penggunaan setiap jenis tes tersebut seyogyanya disesuaikan dengan kawasan (domain) perilaku siswa yang hendak diukur. Misalnya tes tertulis atau tes lisan dapat digunakan untuk mengukur kawasan kognitif, sedangkan kawasan psikomotorik cocok dan tepat bila diukur dengan tes tindakan, dan kawasan afektif biasanya diukur dewngan skala penilaian, seperti skala sikap. (Mudjijo,1995:29). Pada kelas X kebetulan menggunakan Kurikulum 2013 yang mempunyai banyak ranah yang dinilai yaitu ranah kognitif, afektif, dan psikomotorik.

Dari observasi yang peneliti lakukan, peniliti melakukan penilaian sekaligus mengamati seluruh siswa kelas X MIA 3 yang terbagi dalam tiga ranah : 1. Penilaian Hasil Belajar Ranah Kognitif

Evaluasi hasil belajar ranah kognitif di MAN Yogyakarta I secara keseluruhan hasilnya bagus, dikarenakan siswa sudah di beri materi yang banyak di jam sekolah, khusus yang siswa dari pondok justru lebih banyak jam pendalaman materi agama.

Berikut merupakan hasil dokumentasi ranah kognitif yang di peroleh dari nilai ujian tengah semester (UTS) pada Semester Ganjil Kelas X MIA 3 Tahun Ajaran 2014/2015.

Tabel 2.

Daftar Hasil Penilain Hasil Belajar Ranah Kognitif

\begin{tabular}{|c|c|c|c|c|c|c|c|c|}
\hline \multirow{3}{*}{ NO } & \multirow{3}{*}{ NAMA SISWA } & \multirow{2}{*}{\multicolumn{2}{|c|}{$\begin{array}{l}\text { TEMPAT } \\
\text { TINGGAL }\end{array}$}} & \multirow{2}{*}{\multicolumn{4}{|c|}{$\begin{array}{c}\text { PENILAIAN } \\
\text { KOGNITIF } \\
\text { Mata Pelajaran }\end{array}$}} & \multirow{3}{*}{$\begin{array}{l}\text { NILAI } \\
\text { AKHIR }\end{array}$} \\
\hline & & & & & & & & \\
\hline & & $\mathbf{P}$ & $\mathbf{N P}$ & : & $\frac{\nabla}{\mathscr{a}}$ & $\frac{\frac{\pi}{\sigma}}{\frac{\sigma}{2}}$ & 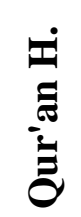 & \\
\hline 1 & $\begin{array}{ll}\text { Afiana } & \text { Nurkholishotus } \\
\text { Shohibah } & \end{array}$ & $\sqrt{ }$ & & 90 & 88 & 96 & 90 & 91 \\
\hline 2 & Arifa Hamida & & $\sqrt{ }$ & 90 & 90 & 95 & 100 & 93.75 \\
\hline 3 & Atiqah Intan Mahardiyanti & & $\sqrt{ }$ & 90 & 90 & 97 & 98 & 93.75 \\
\hline 4 & Dhea Fylla Ifadha & $\sqrt{ }$ & & 85 & 85 & 98 & 100 & 92 \\
\hline
\end{tabular}




\begin{tabular}{|c|c|c|c|c|c|c|c|c|}
\hline 5 & Dwi Unzila Astuti & & $\sqrt{ }$ & 85 & 89 & 92 & 100 & 91.5 \\
\hline 6 & Dzikra Azzahra & & $\sqrt{ }$ & 90 & 89 & 79 & 88 & 86.5 \\
\hline 7 & Elfanty Dhea Syarifa & & $\sqrt{ }$ & 73 & 89 & 85 & 88 & 83.75 \\
\hline 8 & Fatiyah Istiqomah & & $\sqrt{ }$ & 90 & 90 & 83 & 88 & 87.75 \\
\hline 9 & Firnanda Nur Yunisa & & $\sqrt{ }$ & 78 & 90 & 78 & 78 & 81 \\
\hline 10 & Gusti Yohandita Gani & & $\sqrt{ }$ & 90 & 88 & 92 & 85 & 88.75 \\
\hline 11 & Khoiru Nisa Anggraeni & & $\sqrt{ }$ & 75 & 90 & 80 & 80 & 81.25 \\
\hline 12 & Nur Afifah Al Husna & & $\sqrt{ }$ & 90 & 89 & 100 & 85 & 91 \\
\hline 13 & Qonitya Ardinendradewi & & $\sqrt{ }$ & 90 & 89 & 90 & 95 & 91 \\
\hline 14 & $\begin{array}{l}\text { Raden Roro Koesal Viani } \\
\text { Indahsari }\end{array}$ & & $\sqrt{ }$ & 70 & 89 & 85 & 100 & 86 \\
\hline 15 & $\begin{array}{ll}\text { Raisah } & \text { Hulaimah } \\
\text { Nashruddin } & \end{array}$ & & $\sqrt{ }$ & 90 & 85 & 87 & 88 & 87.5 \\
\hline 16 & Sarah Khanifa Assania & & $\sqrt{ }$ & 80 & 87 & 82 & 100 & 87.25 \\
\hline 17 & Shinta Widayasari & & $\sqrt{ }$ & 83 & 88 & 79 & 90 & 85 \\
\hline 18 & Yunny Tri Hanifah & & $\sqrt{ }$ & 90 & 90 & 78 & 100 & 89.5 \\
\hline 19 & Abdullah Harits & $\sqrt{ }$ & & 90 & 90 & 93 & 95 & 92 \\
\hline 20 & Ahsan Jihadan Al-Biruni & $\sqrt{ }$ & & 90 & 70 & 80 & 100 & 85 \\
\hline 21 & Carlo Abimanyu & & $\sqrt{ }$ & 83 & 89 & 90 & 90 & 88 \\
\hline 22 & Faiz Hakim Ramadhan & & $\sqrt{ }$ & 65 & 80 & 80 & 85 & 77.5 \\
\hline 23 & Fajar Awaludin & & $\sqrt{ }$ & 90 & 87 & 82 & 90 & 87.25 \\
\hline 24 & Farkhan Atoillah & $\sqrt{ }$ & & 85 & 90 & 85 & 88 & 87 \\
\hline 25 & Muhammad Fajar B & $\sqrt{ }$ & & 90 & 92 & 97 & 100 & 94.75 \\
\hline 26 & Muhamad Hamdani Itsna & $\sqrt{ }$ & & 90 & 85 & 80 & 100 & 88.75 \\
\hline 27 & $\begin{array}{l}\text { Muhammad } \quad \text { Hanif } \\
\text { Chandra M. }\end{array}$ & $\sqrt{ }$ & & 85 & 92 & 70 & 86 & 83.25 \\
\hline 28 & Muhammad Pitoyo M & & $\sqrt{ }$ & 90 & 93 & 82 & 98 & 90 \\
\hline 29 & Nabhani Ibrahim & $\sqrt{ }$ & & 90 & 90 & 100 & 100 & 95 \\
\hline 30 & Pahlevi Wahyu Hardjita & $\sqrt{ }$ & & 88 & 85 & 80 & 95 & 87 \\
\hline 31 & Ramadhan Iqbal Saputro & $\sqrt{ }$ & & 88 & 90 & 76 & 98 & 88 \\
\hline 32 & Rizky Mubarak Setiadi & $\sqrt{ }$ & & 88 & 88 & 85 & 98 & 89.75 \\
\hline
\end{tabular}




\begin{tabular}{|c|c|c|c|c|c|c|c|c|}
\hline 33 & Taqiyuddin Rabbani & $\sqrt{ }$ & & 88 & 89 & 74 & 100 & 87.75 \\
\hline 34 & $\begin{array}{l}\text { Zhahdo Bintang } \\
\text { Ramadhan }\end{array}$ & & $\sqrt{ }$ & 90 & 88 & 97 & 100 & 93.75 \\
\hline
\end{tabular}

Dari tabel tersebut bisa di simpulkan bahwa dari 13 siswa dari pesantren nilainya lebih unggul dalam pengetahuan kognitifnya dengan rincian sebagai berikut.

Tabel 3

Daftar Jumlah Penilaian Kognitif Berdasarkan Pengelompokan

\begin{tabular}{|l|c|c|c|}
\hline \multirow{2}{*}{ NO } & \multicolumn{2}{|c|}{ SISWA } & \multirow{2}{*}{ NILAI } \\
\cline { 2 - 3 } & PONDOK & NON PONDOK & \\
\hline 1 & 0 & 1 & $<80$ \\
\hline 2 & 2 & 4 & $81-85$ \\
\hline 3 & 6 & 10 & $86-90$ \\
\hline 4 & 5 & 6 & $91-95$ \\
\hline
\end{tabular}

Arah dari penilitian ini adalah untuk mengetahui tingkat kemampuan siswa kelas X MIA 3 dalam dalam pelajaran PAI yang berdampak pada hasil belajar mereka. Hanya 1 siswa yang berasal dari non ponpes mendapatkan ratarata kurang dari 80 atau dengan nilai 77.5, sementara untuk nilai 81-85 ada 2 siswa dari ponpes yang mendapatkan nilai tersebut, kemudian ada 4 siswa dari non ponpes yang mendapatkan nilai 81-85, Sementara untuk nilai $86-90$ ada 6 siswa pesantren yang mendapatkan nilai tersebut berbanding ada 10 siswa non pesantren yang mendapatkan nilai tersebut. Sementara untuk nilai 91-95 siswa dari non pesantren ada 6 siswa, berbanding 5 siswa dari ponpes. Kesimpulan dari nilai pengamatan observasi tersebut, dilihat dari perbandingan jumlah yang kalah dengan siswa non pesantren, maka siswa dari ponpeslah yang begitu mendominasi dalam keaktifan siswa di dalam kelas.

2. Penilaian dan Hasil Belajar Ranah Afektif

Penilaian ranah afektif merupakan penilaian yang terpenting dalam mata pelajaran PAI, sebab inti dari mata pelajaran PAI selain untuk mengembangkan pengetahuan tentang agama yaitu dengan pembentukan watak dan akhlak yang 
berdasarkan pada nilai-nilai agama, yang tumbuh dari pengertian dan pemahamannya terhadap ajaran agama serta keyakinan yang mendalam terhadap ajaran agama. Sesuai dengan pendapat Anas Sudijono bahwa penilaian afektif untuk mengukur perubahan sikap dan nilai.(Anas Sudijono, 2005:54). Apalagi tujuan Kurikulum 2013 ini siswa dituntut untuk bisa menerapkan pada kehidupan sehari-hari, sehingga guru harus pintar dalam menanamkan nilai-nilai agama kepada siswa.

Pentingnya ranah afektif dalam pelajaran PAI ini diikuti dengan persiapan penilaian yang baik yaitu dengan mempersiapkan bentuk-bentuk penilaian. Berikut hasil penilaian dari ranah afktif :

Tabel 4

Daftar Hasil Penilain Hasil Belajar Ranah Afektif

\begin{tabular}{|c|c|c|c|c|c|c|c|c|}
\hline \multirow{3}{*}{$\begin{array}{l}\mathbf{N} \\
\mathbf{O}\end{array}$} & \multirow{3}{*}{ NAMA SISWA } & \multirow{2}{*}{\multicolumn{2}{|c|}{$\begin{array}{c}\text { TEMPAT } \\
\text { TINGGA } \\
\text { L }\end{array}$}} & \multicolumn{4}{|c|}{$\begin{array}{l}\text { PENILAIAN } \\
\text { AFEKTIF }\end{array}$} & \multirow{3}{*}{$\begin{array}{l}\text { NILAI } \\
\text { AKHIR }\end{array}$} \\
\hline & & & & \multicolumn{4}{|c|}{ Mata Pelajaran } & \\
\hline & & $\mathbf{P}$ & NP & : & $\frac{\nabla}{\sigma}$ & $\frac{\frac{\pi}{\sigma}}{\frac{\sigma}{\sigma}}$ & 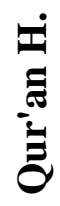 & \\
\hline 1 & $\begin{array}{l}\text { Afiana Nurkholishotus } \\
\text { Shohibah }\end{array}$ & $\sqrt{ }$ & & 75 & 85 & 85 & 75 & 80 \\
\hline 2 & Arifa Hamida & & $\sqrt{ }$ & 75 & 75 & 75 & 75 & 75 \\
\hline 3 & $\begin{array}{l}\text { Atiqah } \\
\text { Mahardiyanti }\end{array}$ & & $\sqrt{ }$ & 70 & 75 & 70 & 70 & 71.25 \\
\hline 4 & Dhea Fylla Ifadha & $\sqrt{ }$ & & 75 & 70 & 75 & 75 & 73.75 \\
\hline 5 & Dwi Unzila Astuti & & $\sqrt{ }$ & 75 & 70 & 85 & 75 & 76.25 \\
\hline 6 & Dzikra Azzahra & & $\sqrt{ }$ & 85 & 70 & 75 & 70 & 75 \\
\hline 7 & Elfanty Dhea Syarifa & & $\sqrt{ }$ & 75 & 70 & 70 & 75 & 72.5 \\
\hline 8 & Fatiyah Istiqomah & & $\sqrt{ }$ & 70 & 75 & 75 & 75 & 73.75 \\
\hline 9 & Firnanda Nur Yunisa & & $\sqrt{ }$ & 75 & 75 & 75 & 70 & 73.75 \\
\hline 10 & Gusti Yohandita Gani & & $\sqrt{ }$ & 75 & 70 & 75 & 75 & 73.75 \\
\hline
\end{tabular}




\begin{tabular}{|c|l|r|r|c|c|c|c|c|}
\hline 11 & Khoiru Nisa Anggraeni & & $\sqrt{ }$ & 70 & 75 & 70 & 75 & 72.5 \\
\hline 12 & Nur Afifah Al Husna & & $\sqrt{ }$ & 70 & 70 & 85 & 75 & 75 \\
\hline 13 & Qonitya Ardinendradewi & & $\sqrt{ }$ & 70 & 75 & 75 & 85 & 76.25 \\
\hline 14 & Raden Roro Koesal Viani & & $\sqrt{ }$ & 75 & 70 & 75 & 75 & 73.75 \\
\hline 15 & Raisah Hulaimah N. & & $\sqrt{ }$ & 75 & 90 & 85 & 85 & 83.75 \\
\hline 16 & Sarah Khanifa Assania & & $\sqrt{ }$ & 70 & 85 & 70 & 70 & 73.75 \\
\hline 17 & Shinta Widayasari & & $\sqrt{ }$ & 70 & 75 & 70 & 70 & 71.25 \\
\hline 18 & Yunny Tri Hanifah & & $\sqrt{ }$ & 70 & 70 & 70 & 70 & 70 \\
\hline 19 & Abdullah Harits & $\sqrt{ }$ & & 75 & 75 & 85 & 85 & 80 \\
\hline 20 & Ahsan Jihadan Al-Biruni & $\sqrt{ }$ & & 75 & 95 & 85 & 85 & 85 \\
\hline 21 & Carlo Abimanyu & & $\sqrt{ }$ & 90 & 75 & 90 & 90 & 86.25 \\
\hline 22 & Faiz Hakim Ramadhan & & $\sqrt{ }$ & 75 & 70 & 75 & 85 & 76.25 \\
\hline 23 & Fajar Awaludin & & $\sqrt{ }$ & 70 & 85 & 75 & 75 & 76.25 \\
\hline 24 & Farkhan Atoillah & $\sqrt{ }$ & & 75 & 75 & 75 & 75 & 75 \\
\hline 25 & Muhammad Fajar B & $\sqrt{ }$ & & 75 & 70 & 85 & 90 & 80 \\
\hline 26 & Muhamad Hamdani Itsna & $\sqrt{ }$ & & 75 & 85 & 85 & 85 & 82.5 \\
\hline 27 & Muhammad Hanif C. & $\sqrt{ }$ & & 75 & 90 & 85 & 85 & 83.75 \\
\hline 28 & Muhammad Pitoyo M & & $\sqrt{ }$ & 75 & 70 & 85 & 85 & 78.75 \\
\hline 29 & Nabhani Ibrahim & $\sqrt{ }$ & & 90 & 75 & 70 & 70 & 76.25 \\
\hline 30 & Pahlevi Wahyu Hardjita & $\sqrt{ }$ & & 85 & 75 & 75 & 85 & 80 \\
\hline 31 & Ramadhan Iqbal Saputro & $\sqrt{ }$ & & 75 & 75 & 75 & 75 & 75 \\
\hline 32 & Rizky Mubarak Setiadi & $\sqrt{ }$ & & 90 & 75 & 75 & 75 & 78.75 \\
\hline 33 & Taqiyuddin Rabbani & $\sqrt{ }$ & & 75 & 85 & 75 & 75 & 77.5 \\
\hline 34 & Zhahdo Bintang R. & & $\sqrt{ }$ & 75 & 85 & 70 & 70 & 75 \\
\hline
\end{tabular}

Dari tabel tersebut bisa di simpulkan bahwa dari 13 siswa dari pesantren nilainya lebih unggul dalam keaktifan dalam kegiatan pembelajaran. dengan rincian sebagai berikut. 
Tabel 5.

Daftar Jumlah Penilaian Afektif Berdasarkan Pengelompokan

\begin{tabular}{|l|c|c|c|}
\hline \multirow{2}{*}{ NO } & \multicolumn{2}{|c|}{ SISWA } & \multirow{2}{*}{ NILAI } \\
\cline { 2 - 3 } & PONDOK & NON PONDOK & \\
\hline 1 & 3 & 14 & $70-75$ \\
\hline 2 & 7 & 5 & $76-80$ \\
\hline 3 & 3 & 2 & $81-85$ \\
\hline
\end{tabular}

Sebanyak 14 yang berasal dari non ponpes mendapatkan nilai 70-75, sementara 3 siswa mendapatkan nilai tersebut. untuk nilai 76-80 ada sebanyak 7 siswa dari ponpes yang mendapatkan nilai tersebut, dan hanya 5 siswa non ponpes. Sementara untuk nilai $81-85$ ada 3 siswa pesantren yang mendapatkan nilai tersebut berbanding hanya ada 2 siswa non pesantren yang mendapatkan nilai tersebut. Jika dilihat dari jumlah siswa yang lebih banyak siswa non pesantren, maka dengan perbandingan hasil diatas tentunya siswa ponpes nilainya dan keaktifannya lebih dominan dengan siswa non pesantren.

3. Evaluasi Hasil Belajar Ranah Psikomotorik

Hasil belajar Psikomotorik siswa Kelas X MIA 3 cukup baik. hal itu bisa dilihat dari beberapa mata pelajaran PAI yang penulis observasi dikelas tersebut. Hasilnya siswa yang bertempat tinggal di pondok pesantren begitu mendominasi dalam penguasaan materi mata pelajaran PAI. Sebagai contoh ketika berdiskusi, siswa dari ponpes yang kebanyakan aktif dan yang menguasai materi pelajaran tersebut.

ketika siswa dalam proses pembelajaran Fiqih yang diampu oleh Bapak Dzulhaq, pada ranah Psikomotorik berkenaan dengan ketrampilan (skill) dan kemampuan bertindak individu dalam pengaplikasiannya, pada saat pembelajaran fiqih dengan materi wakaf, siswa mempraktekkan cara wakaf, para siswa terlebih dahulu menonton video tentang tata cara proses ikrar wakaf, setelah menonton dan punya gambaran tentang wakaf, maka siswa mempraktekkan prosesi ikrar wakaf dengan kelompok/tugas yang sudah dibagikan sebelumnya. Dengan praktek langsung seperti itu diharapkan siswa menjadi aktif dalam bertindak dan 
tentunya mempunyai kemampuan menguasi materi lewat keterampilan mempraktekannya.

\section{Kelebihan dan kekurangan dari penerapan dua kurikulum tersebut}

a. Kelebihan dari penerapan dua kurikulum (Kurikulum Kementrian Agama dan Kurikulum Pesantren).

Secara umum, kurikulum pesantren mempunyai peran yang sangat besar terhadap hasil belajar siswa di madrasah, berikut adalah kelebihan dari penerapan dua kurikulum tersebut :

Kurikulum kemenag di madrasah dengan kurikulum pesantren di ponpes jika diterapkan secara baik, akan membuat siswa semakin banyak menguasai materi pelajaran agama, sehingga akan mendongkrak nilai ujian disekolah dan mengangkat prestasinya. Namun harus ada kesinambungan antara pelajaran di madrasah dengan pelajaran di ponpes hal tersebut dikarenakan kurikulum pesantren diatur oleh lembaga / instansi itu sendiri, oleh karena itu kurikulum pesantren harus menyesuaikan dengan materi pelajaran yang diajarkan di kurikulum kemenag.

Jika disekolah kebanyakan hanya di ajarkan tentang teori saja, maka dengan penerapan dua kurikulum tersebut, diharapkan siswa dapat belajar langsung dari pengalaman yang timbul sehari-hari dan menanyakan (studi) kasus secara langsung dengan dewan guru (ustadz) yang bersangkutan. Proses belajar mengajar dilakukan 24 jam sehari semalam, baik di sekolah maupun di ponpes, adanya pengawasan dari pihak ponpes dan sekolah akan membuat perilaku siswa yang menyimpang, akan tertanggulangi secara langsung.

Dengan bimbingan dan asuhan pendidik langsung pada santri yang dilakukan di dalam asrama dan kelas, akan membuat santri selalu terkontrol dalam belajar sehingga hasil belajar di sekolah maupun di ponpes akan mendapat nilai yang memuaskan.

b. Kekurangan dari penerapan dua kurikulum (Kurikulum Kementrian Agama dan Kurikulum Pesantren)

Terjadi ketidak sesuian antar kurikulum kementerian agama dan kurikulum pesantren, karena materi yang tidak disampaikan secara berurutan. 
Seperti dalam Fiqih. Kalau di pesantren kitabnya bab awal membahas tentang thoharoh, sedangkan di sekolah mempelajari bab Haji. Contoh lain pada pelajaran Bahasa Arab, kalau dipesantren terlebih dahulu mempelajari Kalimah, sedangkan di sekolah langsung membahas tentang Naat Man'ut. Namun secara hasil pada penilaian, memang siswa yang di ponpes sedikit lebih unggul dibanding dengan siswa non pesantren.

Dari alokasi waktu di kurikulum pesantren tidak sebanding dengan kurikulum kemenag, dikarenakan alokasi waktu di sekolah sangat mencukupi yaitu sekitar 8 jam pelajaran, sedangkan kurikulum pesantren waktunya hanya dikasih 1 jam pelajaran. Alokasi waktu yang tidak sebanding itu tentu menyebabkan masalah, seolah-olah kurikulum pesantren hanya menjadi kurikulum yang di nomer dua-kan. Hal itu tentu juga berpengaruh pada kesempatan santri dalam proses belajar-mengajar, padahal kurikulum pesantren materinya lebih komprehensif.

Padatnya jadwal di sekolah yaitu mulai jam 07.00 sampai jam 15.00 akan membuat siswa lelah, belum ditambah dengan kegiatan ekstra kurikuler dan hanya ada jeda satu jam untuk istirahat tentunya akan membuat siswa masih lelah

Ada tiga kurikulum yang diterapkan di MAN Yogyakarta I, yakni kurikulum Kemendiknas, Kemenag dan Kurikulum Pesantren yang ada di ponpes sendiri, dalam pelaksanaannya, kurikulum Kemenag dan Kurikulum Pesantren berjalan berdampingan dan saling melengkapi. Namun dengan penerapan tiga kurikulum tersebut dikhawatirkan mempengaruhi konsentrasi berpikir siswa untuk membagi waktu, karena disamping memikirkan ujian yang dilaksanakan oleh Kemendiknas seperti Ujian Nasional (UN) setelah itu siswa di tuntut untuk memikirkan ujian yang dilaksanakan oleh Kemenag seperti UAMBN, dan masih harus belajar materi Kurikulum Pesantren. Oleh karena itu siswa harus bisa membagi waktu dan berpikir secara ekstra agar bisa memperoleh hasil maksimal di Kurikulum Kemendiknas, Kemenag dan Pesantren.

Tetapi PP. Al Hakim adalah pondok yang mengikuti aturan sekolahnya, sehingga apapun kegiatan yang dilaksanakan oleh pihak ponpes harus tidak menganggu kegiatan di MAN Yogyakarta I. 
Namun menurut Nurcholis Madjid mensinyalir bahwa tujuan pendidikan pesantren pada umumnya diserahkan kepada proses improvisasi menurut perkembangan pesantren yang dipilih sendiri oleh Kiai atau bersamasama pembantunya secara intuitif.(Dwi Priyanto,2006:7) Itu artinya Kiai di ponpes sebagai orang yang merencanakan kurikulum pesantren, berbeda dengan di sekolah yang kurikulumnya sudah terencana secara sistematis dan struktur.

Kekurangan yang lain adalah dalam pelaksanaannya, Kurikulum Kemenag dari segi metode dan strateginya lebih inovatif dan kreatif, karena di tunjang waktu yang lama dan materi pelajaran yang sedikit., kalau kurikulum Pesantren materi pelajaran cakupannya sangat luas dan mendalam namun hanya di tunjang waktu yang sedikit dalam proses pembelajarannya, sehingga Ustadz di ponpes tidak bisa menerapkan metode dan strategi yang kreatif dan inovatif.

Setiap siswa/santri pasti punya tipe-tipe yang berbeda-beda dalam hal memilih tempat untuk belajar, namun ketika di ponpes/sekolah sedikit sekali tempat ponpes yang cocok untuk tempat konsentrasi dalam belajar, karena kalau ada keramaian tentu akan terganggu konsentrasi dalam berfikir. Karena PP. Al Hakim adalah ponpes milik Madrasah, maka semua program harus menyesuaikan program Madrasah. Sehingga terkadang lingkungan belajar ponpes terganggu.

\section{Kesimpulan}

Dalam penerapan kurikulum Kemenag dan kurikulum Pesantren mempunyai dampak positif terhadap hasil belajar siswa yang tinggal di pesantren. Dari hasil penelitian yang penulis lakukan, diketahui bahwa hasil belajar siswa yang tinggal di pesantren dari ranah kognitif, afektif dan psikomotorik pencapaiannya lebih unggul jika di bandingkan dengan siswa non pesantren. Keunngulan tersebut terlihat dari nilai ujian, penguasaan dan pemahaman materi pelajaran, dan yang terakhir tentang keaktifan di kelas. Kurikulum kemenag dengan kurikulum pesantren jika diterapkan secara baik, akan membuat siswa semakin banyak menguasai materi pelajaran agama, sehingga akan mendongkrak nilai ujian disekolah khusunya pada bidang mata pelajaran agama dan akan mengangkat prestasinya. Beberapa kekurangan penerapan dua kurikulum adalah : Terjadi ketidak sesuaian antara materi kurikulum kemenag dan kurikulum pesantren, karena materi yang tidak disampaikan secara berurutan. Dan dari 
alokasi waktu di kurikulum pesantren tidak sebanding dengan kurikulum kemenag.

\section{Daftar Pustaka}

Chamid, Abu, (2013) “Tansformasi Kurikulum Pesantren (Studi Kasus Pesantren Futuhiyyah Mranggen Demak)”, Skripsi, Fakultas Tarbiyah IAIN Walisongo.

Masyhud, Sulthon, dkk, (2005.), Manajemen Pondok Pesantren,Jakarta: Diva Pustaka.

Mudjijo, (1995), Tes Hasil Belajar, Jakarta: Bumi Aksara.

Nurhayati, Anin, (2010), Inovasi Kurikulum : Telaah Terhadap Pengembangan Kurikulum Pendidikan Pesantren, Yogyakarta: Teras.

Priyanto, Dwi, (2006), Inovasi Kurikulum Pesantren (Memproyeksikan Model Pendidikan Alternatif Masa Depan), Ibda' Jurnal Studi Islam dan Budaya: P3M STAIN Purwokerto.

Sudijono, Anas, (2005), Pengantar Evaluasi Pendidikan, Jakarta: RajaGrafindo Persada. 